\title{
Pressure injury related to the use of personal protective equipment in COVID-19 pandemic
}

\author{
Lesão por pressão relacionada ao uso de equipamentos de proteção individual na pandemia da COVID-19 \\ Lesión por presión relacionada al uso de equipos de protección personal en la pandemia del COVID-19
}

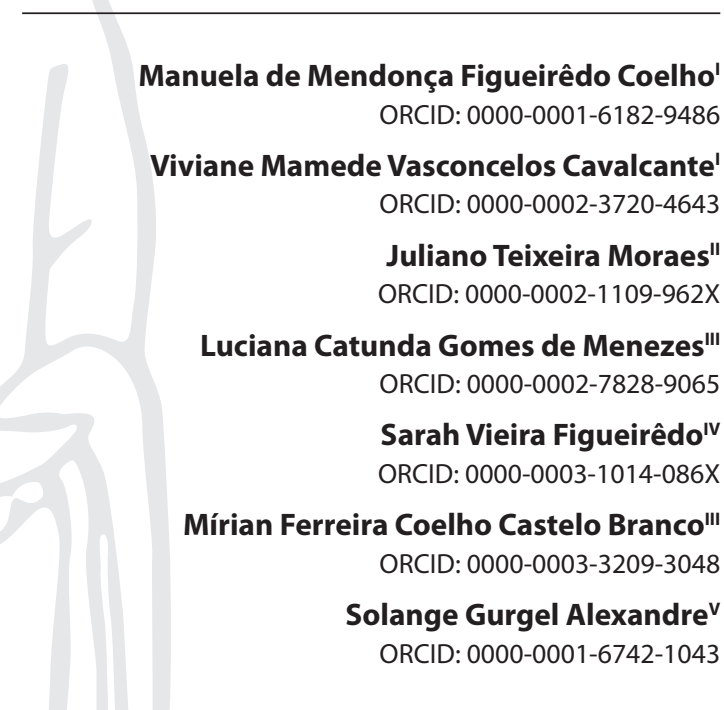

'Universidade Federal do Ceará. Fortaleza, Ceará, Brazil. "Universidade Federal de São João del-Rei. São João del-Rei, Minas Gerais, Brazil.

II' Centro Universitário UNIFAMETRO. Fortaleza, Ceará, Brazil.

"Universidade Estadual do Ceará. Fortaleza, Ceará, Brazil. ${ }^{v}$ Hospital Walter Cantídeo. Fortaleza, Ceará. Brazil.

How to cite this article: Coelho MMF, Cavalcante VMV, Moraes JT, Menezes LCG, Figueirêdo SV, Branco MFCC, et al. Pressure injury related to the use of personal protective equipment in COVID-19 pandemic. Rev Bras Enferm. 2020;73(Suppl 2):e20200670. doi: http://dx.doi.org/10.1590/0034-7167-2020-0670

Corresponding author:

Manuela de Mendonça Figueirêdo Coelho

E-mail: manumfc2003@yahoo.com.br

EDITOR IN CHIEF: Dulce Barbosa ASSOCIATE EDITOR: Mitzy Reichembach

\section{ABSTRACT}

Objective: To describe the prevalence and factors associated with pressure injuries related to the use of personal protective equipment during the COVID-19 pandemic. Methods: Cross-sectional study conducted using an instrument made available in social networks with 1,106 health professionals. The data were analyzed using descriptive statistics and compared, considering pvalue $<0.05$. Results: There was a prevalence of $69.4 \%$ for pressure injuries related to the use of personal protective equipment, with an average of 2.4 injuries per professional. The significant factors were: under 35 years of age, working and wearing personal protective equipment for more than six hours a day, in hospital units, and without the use of inputs for protection. Conclusion: Pressure injuries related to the use of medical devices showed a high prevalence in this population. The recognition of the damage in these professionals makes it possible to advance in prevention strategies.

Descriptors: Personal Protective Equipment; Pressure Ulcer/Injury; Healthcare Personnel; Coronavirus; Pandemics.

\section{RESUMO}

Objetivo: Descrever prevalência e fatores associados da lesão por pressão relacionada ao uso de equipamentos de proteção individual durante a pandemia da COVID-19. Métodos: Estudo transversal realizado por meio de instrumento disponibilizado em redes sociais com 1.106 profissionais de saúde. Os dados foram analisados por meio de estatística descritiva e comparada, considerando valor de $p<0,05$. Resultados: Houve prevalência de $69,4 \%$ para lesão por pressão relacionada ao uso do equipamento de proteção individual, com uma média de 2,4 lesões por profissional. Os fatores significativos foram: menores de 35 anos de idade, trabalhar e fazer uso de equipamentos de proteção individual por mais de seis horas no dia, em unidades hospitalares e sem o uso de insumos para proteção. Conclusão: A lesão por pressão relacionada ao uso de dispositivos médicos apresentou alta prevalência nessa população. $O$ reconhecimento da lesão nesses profissionais possibilita avançar em estratégias de prevenção.

Descritores: Equipamento de Proteção Individual; Lesão por Pressão; Pessoal de Saúde; Coronavírus; Pandemias.

\section{RESUMEN}

Objetivo: Describir prevalencia y factores relacionados a la lesión por presión relacionada al uso de equipos de protección personal durante la pandemia del COVID-19. Métodos: Estudio transversal realizado mediante instrumento disponible en redes sociales con 1.106 profesionales de salud. Los datos han analizados por medio de estadística descriptiva y comparada, considerando valor de $p<0,05$. Resultados: Hubo prevalencia de $69,4 \%$ para lesión por presión relacionada al uso del equipo de protección personal, con una media de 2,4 lesiones por profesional. Los factores significativos fueron: menores de 35 años de edad, trabajar y hacer uso de equipos de protección personal por más de seis horas al día, en unidades hospitalarias y sin el uso de suministros para protección. Conclusión: La lesión por presión relacionada al uso de dispositivos médicos presentó alta prevalencia en esa población. El reconocimiento de la lesión en esos profesionales posibilita avanzar en estrategias de prevención.

Descriptores: Equipo de Protección Personal; Lesión por Presión; Personal de Salud; Coronavirus; Pandemias. 


\section{INTRODUCTION}

The coronavirus disease, also known as COVID-19, is caused by a new coronavirus, appeared in Wuhan, China, in December 2019. It is a respiratory disease, extremely infectious, which presents various clinical conditions and various symptoms. The patient may present, among other symptoms, fever (83\%-99\%), cough (59\%$82 \%)$, fatigue (44\%-70\%), anorexia (40\%-84\%), shortness of breath (31\%-40\%), expectoration (28\%-33\%) and myalgia (11\%-35\%) $)^{(1-3)}$.

Many infected people will present the mildest form of the disease and will not need hospital admission. However, $14 \%$ of the patients may develop the severe form of the disease, requiring oxygen therapy, and at least $5 \%$ will evolve with pneumonia, a more severe clinical form, requiring an Intensive Care Unit bed, with specialized professional assistance, and possibly the use of a mechanical ventilator ${ }^{(4)}$.

By May 18, 2020, there were more than 4 million confirmed cases and more than 300,000 deaths, with a lethality rate of $6.7 \%$ worldwide. In the same period, Brazil had more than 240 thousand cases and almost 17 thousand deaths, being the fourth country in several confirmed cases and the sixth in many deaths. Since the beginning of the pandemic, the state of Ceará has shown a higher number of cases and deaths, presenting a lethality rate of $6.8 \%$, and $97.3 \%$ of cities with confirmed cases ${ }^{(5)}$.

Among infected people, it shall be pertinent to highlight the high number of health professionals. The Brazilian Ministry of Health disclosed on May 14, 2020, that the country had, until then, 31,790 infected health professionals and that the number of workers with suspicion of COVID-19 reached 199,768. According to the records, technicians and nursing auxiliaries lead the list of categories with more infected people, 68,250 (34.2\%); followed by nurses, 33,733 (16.9\%); physicians, 26,546 (13.3\%); physiotherapists, 4,179 (2.1\%); among other health professions. In this reality, Ceará is in third place in the number of confirmed cases per state, being only behind the states of São Paulo and Rio de Janeiro(5).

To contain the spread of the infection, the World Health Organization indicates personal protective equipment (PPE) by all professionals in health care sites. Thus, the use of gloves, surgical masks, goggles or face protection, and surgical gowns are indispensable, as well as items for specific procedures, such as the use of respirators, N95 classification masks, filtering facial parts (PFF2) or equivalent standard and aprons ${ }^{(6)}$.

Healthcare professionals face significant charges with coronavirus infections. Studies have shown that the use of PPE and training in infection control are associated with decreased risk of infection, while specific exposures are related to increased risk of infection ${ }^{(7)}$.

However, some issues are imbricated/overlapped in the use of PPE during the pandemic. An important point to consider is the availability of these inputs. A study conducted in Jordan pointed out that only $18.5 \%$ of medical professionals caring for patients with COVID-19 had access to PPEs ${ }^{(8)}$. Although health professionals are acting tirelessly, the inadequate inputs of equipment created discouragement among the workers, as well as triggering concerns about the risk to which they expose themselves and their families ${ }^{(9)}$.

Another relevant issue regarding EPPs relates to the dermatological manifestations associated with prolonged use and the pressure they imprint on the site of use. Social networks have often presented images of professionals with skin lesions, caused mainly by the $\mathrm{N} 95$ mask.

So far, there is only one work (Chinese) in the world literature that describes the occurrence of these lesions, thus justifying the development of this study. This work evaluated 1,844 health professionals, who presented an average of up to 2.6 lesions per person. The highest prevalence $(42.8 \%)$ found was for lesion due to pression-related through medical device (Medical Device-related Pressure Injury), followed by moisture and friction injury, with $30 \%$ and $2 \%$, respectively ${ }^{(10)}$.

\section{OBJECTIVE}

Describe the prevalence and associated factors of pressure injuries related to the use of personal protective equipment during the COVID-19 pandemic.

\section{METHODS}

\section{Ethical Aspects}

Following the ethical precepts for research with human beings and approved by the Brazilian Research Ethics Committee. The participants received and electronically signed the Informed Consent Term, and anonymity was assured.

\section{Design, location, and period of the study}

The research is a transversal descriptive study with a quantitative approach, guided by the STROBE tool. Conducted between 15 and 20 May 2020, in Ceará, it has the largest number of cases of COVID-19 among states in the Northeastern Region of Brazil. Until May 20, 2020, 30.560 cases presented the laboratory criteria, of which $58.9 \%$ occurred in the city of Fortaleza, capital of Ceará(5).

\section{Population and sample}

The population was composed of 81.426 health professionals, with active registration in the respective state class council, in the following categories: physicians (15.506), nursing professionals (56.323), and physiotherapist (9.597).

The sample was of the convenience type, considering a $3 \%$ sample error and $95 \%$ confidence interval $(\mathrm{Cl})$, totaling, in the end, 1.106 professionals, with the following stratification: 741 nursing professionals, 242 physicians, and 123 physiotherapists.

\section{Inclusion and exclusion criteria}

As inclusion criteria, professionals acting directly in the care of patients with COVID-19 were considered during the data collection period. Professionals who returned incomplete instruments were excluded, as well as those who reported not using PPE.

\section{Study Protocol}

For data collection, the team made available a semi-structured questionnaire on Google Forms, through social networks (WhatsApp, Instagram, Facebook) for health professionals in Ceará. This 
tool included the following variables: socio-professional data, information related to the use of PPE, presence of injury related to PPE, types of injuries and anatomical locations, and preventive measures used (if used).

The presence of lesions was considered a dependent variable. The independent variables were: gender, professional category, time of daily use of PPE (in hours), workplace (if it works in the hospital area or other services such as Basic and Secondary Care), if it used some input to protect itself from injuries from PPEs, relief of PPE pressure every two hours, time of hours worked per day (up to six hours or more, Considering that higher workload requires longer PPE use time and, usually, the minimum hour load of a shift is usually six hours), as well as age (with dichotomization of values below and above 35 years, based on other studies according to which a considerable portion of the population of health professionals is in this age group). For bivariate analysis between the variables, it is explicit that the professional categories "physician" and "physiotherapist" were grouped in a single class for the calculation of the odds and accomplishment of the association with the nursing, considering that this is the predominant category of the study.

To classify Medical Device-related Pressure Injury, the gradual classification system of pressure lesions was used: Stage 1 Pressure Injury (PL1) - intact skin, with redness that does not whiten, changes in sensitivity, temperature and consistency may precede visual changes; Stage 2 Pressure Injury (PL2) - loss of skin in partial thickness, with exposure of the dermis, the wound is pink or red, moist, and may also present as an intact or ruptured blister, fat tissue and deep tissues are not visible; Stage 3 Pressure Injury (PL3) - loss of skin in total thickness, in which fat is visible, there is no exposure of fascia, muscle, tendon, ligament, cartilage and/or bone; Stage 4 (PL4) - loss of skin in total thickness and tissue loss with exposure or direct palpation of the fascia, muscle, tendon, ligament, cartilage, or bone; Deep Tissue Pressure Injury (DTPI) intact or unbroken skin with localized, persistent area of dark red, brown, or purple discoloration that does not whiten, or epidermal separation that shows a darkened bed lesion or bleb with bloody exudate. Due to the DTPI characteristics, it is impossible to define the lesion in any of the classifications presented previously ${ }^{(11)}$.

\section{Analysis of results and statistics}

The data were typed in Excel $^{\circledR}$ spreadsheets, later exported to the Statistical Package for the Social Sciences (SPSS), version 23.0. Descriptive statistical tests were performed (simple and absolute frequencies, mean, standard deviation). Regarding the variables related to skin lesions, the point prevalence was calculated. Fisher's exact and Pearson's chi-square tests were applied for the association between explanatory variables, considering $p$-value $<0.05$, odds ratio, $95 \%$ confidence interval $(95 \% \mathrm{Cl})$, and binary hierarchical logistic regression for variables that presented significant values in bivariate analysis. The variables were adjusted and only those with statistical significance were kept in the final model.

\section{RESULTS}

One thousand and one hundred six health care professionals from 96 cities participated in the survey, involving the capital, metropolitan region, and interior of Ceará. The sample was composed of 925 (83.6\%) female professionals, 509 (46.1\%) singles, with a mean age of 34.08 years (standard deviation, 8.9), being $632(57.1 \%)$ under 35 years old. On average, the professionals had $9.55( \pm 13.4)$ years of training and an average workload of $10.7( \pm 3.9)$ hours. In Table 1 is presented the socio-professional characterization.

Regarding the use of PPEs, 972 (87.9\%) reported using it always during the patient's care with COVID-19. Among the justifications for those who did not make frequent use, 11 (8.1\%) participants reported forgetfulness, 118 (86.8\%), lack of PPE availability in the service; and 7 (5.1\%) did not consider it necessary. The average time of PPE use was $9.15 \mathrm{~h} \mathrm{(} \pm 3.6)$, in which 306 (27.7\%) used the equipment for up to six hours daily and 800 (72.3\%) for more than six hours daily.

Among the most used PPE, the cap and gloves were indicated, with a frequency of 989 (89.4\%) and 945 (85.4\%), respectively. The use of apron was referred by 873 (78.9\%); N95 mask, by 787 (71.2\%); face protector, by 740 (66.9\%); surgical mask, by 726 (65.6\%); glasses, by 529 (47.8\%); and PFF2 mask, by 360 (32.5\%).

Regarding the occurrence of skin lesions, its prevalence was $69.4 \%$ among all participants. These lesions had a more significant occurrence among nursing professionals, 509 (66.1\%); in 179 (23.2\%) of physicians; and in $82(10.7 \%)$ of physiotherapists. The prevalence in these professionals was $68.7 \%$ in the nursing team, $74 \%$ among physicians, and $66.7 \%$ among physiotherapists.

In all, there were 1,880 pressure injuries related to the use of PPE, with an average of 2.4 per professional. These lesions were processed and presented a punctual prevalence according to these classifications: PL1 = 675 (67\%), PL2 = 19 (8.4\%) and DTPI $=1(0.4 \%)$. The nasal bone region presented the highest number of Medical Device-related Pressure Injury, with a record of 596 (31.7\%) lesions in this area, according to Table 2.

A bivariate analysis was performed between the outcome and the independent variables, in which there was an association for the appearance of Medical Device-related Pressure Injury in those professionals under 35 years of age $(p=0.003)$, who worked and made use of PPE for more than six hours in the day ( $p=0.004$ and $p=0.000$, respectively), in-hospital units ( $p=$ $0.005)$ and without the use of inputs for protection $(p=0.000)$, according to Table 3 .

When one notices the association to the age under 35 and the injury presentation obtaining odds of 0.652 , people that age had a decreased chance of developing lesions, as corroborated by the regression model.

Hierarchical binary logistic regression analysis was performed, in which presence of injury was defined as dependent variable $(0=$ No, $1=$ Yes) and single factors with $p<0.05$ after bivariate analysis (Table 3); and the independent variables were: no use of protective input $=1$; age up to 35 years $=1$; time of PPE daily use $>6$ hours/day $=1$; working in hospital $=1$; and daily work time $>6$ hours/day $=1$.

The variables "workplace" and "daily work time" were removed from the final logistic model, as they did not present significant values, had little adherence, representing an unfavorable influence on the model. The model containing three variables was considered significant and is presented in Table 4. 
Table 1 - Socio-professional characterization by category of health care professionals in the state of Ceará, Brazil, 2020 ( $\mathrm{n}=1$,106)

\begin{tabular}{|c|c|c|c|c|c|c|c|c|}
\hline \multirow{2}{*}{ Variables } & \multicolumn{2}{|c|}{ Nursing professional } & \multicolumn{2}{|c|}{ Physician } & \multicolumn{2}{|c|}{ Physiotherapist } & \multicolumn{2}{|c|}{ Total } \\
\hline & $\mathbf{n}$ & $\%$ & $\mathbf{N}$ & $\%$ & $\mathbf{N}$ & $\%$ & $\mathbf{n}$ & $\%$ \\
\hline \multicolumn{9}{|l|}{ Gender } \\
\hline Male & 77 & 10.4 & 82 & 33.9 & 22 & 17.9 & 181 & 16.37 \\
\hline Female & 664 & 89.6 & 160 & 66.1 & 101 & 82.1 & 925 & 83.63 \\
\hline \multicolumn{9}{|l|}{ Marital Status } \\
\hline Single & 348 & 47.0 & 113 & 46.7 & 48 & 39.0 & 509 & 46.1 \\
\hline Married & 271 & 36.6 & 99 & 40.9 & 62 & 50.4 & 432 & 39.1 \\
\hline Common law marriage & 67 & 9.0 & 21 & 8.7 & 08 & 6.5 & 96 & 8.6 \\
\hline Divorced & 50 & 6.7 & 09 & 3.7 & 05 & 4.1 & 64 & 5.7 \\
\hline Widow (er) & 05 & 0.7 & 00 & 00 & 00 & 00 & 05 & 0.5 \\
\hline \multicolumn{9}{|l|}{ City of Work } \\
\hline Capital of Ceará & 485 & 65.5 & 171 & 70.7 & 95 & 77.2 & 751 & 68.0 \\
\hline Metropolitan Region/Rural area & 256 & 34.5 & 71 & 29.3 & 28 & 22.8 & 355 & 32.0 \\
\hline \multicolumn{9}{|l|}{ Age (years) } \\
\hline$\leq 35$ & 448 & 60.5 & 170 & 70.2 & 69 & 56.1 & 687 & 62.1 \\
\hline$>35$ & 293 & 39.5 & 72 & 29.8 & 54 & 43.9 & 419 & 37.9 \\
\hline \multicolumn{9}{|l|}{ Time of daily work (hours) } \\
\hline$\leq 6$ & 86 & 11.6 & 22 & 9.1 & 33 & 26.8 & 141 & 12.7 \\
\hline$>6$ & 655 & 88.4 & 220 & 90.9 & 90 & 73.2 & 965 & 87.3 \\
\hline
\end{tabular}

Table 2 - Distribution of pressure lesions, according to classification and anatomical locations in health care professionals in the state of Ceará, Brazil, 2020 ( $\mathrm{n}=1.880$ )

\begin{tabular}{|c|c|c|c|c|c|c|c|c|c|c|c|c|}
\hline & \multicolumn{2}{|c|}{ Forehead } & \multicolumn{2}{|c|}{ Nasal Bone } & \multicolumn{2}{|c|}{ Nasal Wing } & \multicolumn{2}{|c|}{ Zygomatic } & \multicolumn{2}{|c|}{ Ear } & \multicolumn{2}{|c|}{ Cheeck } \\
\hline & $\mathbf{n}$ & $\%$ & $\mathbf{n}$ & $\%$ & $\mathbf{n}$ & $\%$ & n & $\%$ & $\mathbf{n}$ & $\%$ & $\mathbf{n}$ & $\%$ \\
\hline $\mathrm{PL}^{*}(\mathrm{n}=1.734)$ & 333 & 19.2 & 515 & 29.7 & 131 & 7.5 & 219 & 12.7 & 328 & 18.9 & 208 & 12.0 \\
\hline $\mathrm{PL}^{+}(\mathrm{n}=115)$ & 06 & 5.2 & 70 & 60.9 & 10 & 8.7 & 09 & 7.9 & 12 & 10.4 & 08 & 6.9 \\
\hline $\mathrm{DTPI}^{\ddagger}(\mathrm{n}=31)$ & 08 & 25.8 & 11 & 35.5 & 05 & 16.1 & 01 & 3.2 & 03 & 9.7 & 03 & 9.7 \\
\hline Total $(n=1.880)$ & 347 & 18.5 & 596 & 31.7 & 146 & 7.8 & 229 & 12.1 & 343 & 18.4 & 219 & 11.5 \\
\hline
\end{tabular}

Notes: ${ }^{*}$ Stage pressure injury $1 ;{ }^{+}$Stage pressure injury $2 ;{ }^{*}$ Deep tissue pressure injury.

Table 3 - Association between the presence of injuries in health care professionals in the state of Ceará, Brazil, 2020 $(n=768)$

\begin{tabular}{|c|c|c|c|c|c|}
\hline \multirow{2}{*}{ Characteristics } & \multicolumn{4}{|c|}{ Presence of lesions } & \multirow[b]{2}{*}{$p$ value ${ }^{\dagger}$} \\
\hline & $\mathbf{n}$ & Prevalence (\%) & Odds ratio & $\mathrm{Cl}^{*} 95 \%$ & \\
\hline \multicolumn{3}{|l|}{ Gender } & 0.747 & $0.535-1.045$ & 0.870 \\
\hline Male & 116 & 64.1 & & & \\
\hline Female & 652 & 70.5 & & & \\
\hline \multicolumn{3}{|l|}{ Profession } & 1.136 & $0.863-1.495$ & 0.364 \\
\hline Nurse & 508 & 68.6 & & & \\
\hline Physician/Physiotherapist & 260 & 71.2 & & & \\
\hline \multicolumn{3}{|l|}{ Time of PPE daily use $e^{\ddagger}$ hours) } & 1.987 & $1.505-2.624$ & 0.000 \\
\hline$\leq 6$ & 180 & 58.8 & & & \\
\hline$>6$ & 584 & 74.2 & & & \\
\hline \multicolumn{3}{|l|}{ Relieves the pressure of $\mathrm{PPE}^{\ddagger}$ every 2 hours } & 0.861 & $0.652-1.137$ & 0.291 \\
\hline No & 549 & 70.4 & & & \\
\hline Yes & 219 & 67.2 & & & \\
\hline \multicolumn{3}{|l|}{ Place of work } & 1.689 & $1.533-1.892$ & 0.005 \\
\hline Hospital & 412 & 73.3 & & & \\
\hline Other institutions & 356 & 65.4 & & & \\
\hline \multicolumn{3}{|l|}{ Use of protection inputs } & 72.763 & $23.13-228.84$ & 0.000 \\
\hline No & 465 & 58.1 & & & \\
\hline Yes & 303 & 99.0 & & & \\
\hline \multicolumn{3}{|l|}{ Daily working time (hours) } & 1.710 & $1.189-2.458$ & 0.004 \\
\hline$\leq 6$ & 83 & 58.9 & & & \\
\hline$>6$ & 685 & 72.0 & & & \\
\hline \multicolumn{3}{|l|}{ Age (years) } & 0.652 & $0.527-0.882$ & 0.003 \\
\hline$\leq 35$ & 461 & 72.9 & & & \\
\hline$>35$ & 307 & 64.8 & & & \\
\hline
\end{tabular}

Notes: ${ }^{*}$ Confidence interval; ${ }^{+}$Pearson chi-square test $;{ }^{\ddagger}$ Personal protection equipment.

Table 4 - Final logistic regression model — Fortaleza - CE, Brazil, 2020

\begin{tabular}{|c|c|c|c|c|c|}
\hline & \multirow[b]{2}{*}{$\mathbf{B}(\mathrm{EP})^{*}$} & \multirow[b]{2}{*}{$\mathbf{p}^{+}$} & \multicolumn{3}{|c|}{$\mathrm{Cl}^{\ddagger} 95 \%$ for $\operatorname{Exp} \mathrm{b}$} \\
\hline & & & Inferior & $\operatorname{Exp} \mathbf{b}$ & Superior \\
\hline \multicolumn{6}{|l|}{ Included } \\
\hline Constant & $0.117(0.144)$ & & & & \\
\hline Use of prevention inputs & $4.245(0.585)$ & 0.000 & 22.148 & 69.731 & 219.543 \\
\hline Age up to 35 years & $-0.495(0.147)$ & 0.001 & 0.457 & 0.609 & 0.813 \\
\hline Usage of equipament for over 6 hours & $0.609(0.156)$ & 0.000 & 1.353 & 1.838 & 2.496 \\
\hline
\end{tabular}


Pressure injury related to the use of personal protective equipment in COVID-19 pandemic Coelho MMF, Cavalcante VMV, Moraes JT, Menezes LCG, Figueirêdo SV, Branco MFCC, et al.

Table 5 - Inputs used by health professionals for prevention of pressure related injuries related to the use of Personnel Protection Equipment - Ceará, Brazil, 2020

\begin{tabular}{|c|c|c|c|c|c|c|}
\hline & \multirow[b]{2}{*}{$\mathbf{n}$} & \multicolumn{4}{|c|}{ Prevented } & \multirow{2}{*}{$p$ value } \\
\hline & & $\%$ & Inferior & Odds ratio & Superior & \\
\hline \multicolumn{7}{|l|}{ Inputs } \\
\hline Foam & 11 & 91.7 & 0.150 & 1.204 & 9.655 & 1.000 \\
\hline Silicone & 16 & 100 & 0.861 & 0.895 & 1.931 & 0.384 \\
\hline Transparent Film & 40 & 97.6 & 0.663 & 5.000 & 37.702 & 0.097 \\
\hline Extra slim hydrocolloid dressing & 29 & 40.3 & 1.335 & 4.231 & 13.454 & 0.010 \\
\hline Adhesive tape/Microporous adhesive & 44 & 18.7 & 0.079 & 0.251 & 0.797 & 0.020 \\
\hline
\end{tabular}

Note: *Fisher's exact test

The age 35 years presented a negative relation with the outcome, configuring that this age group is a protective factor in relation to the development of lesions, evidenced by the Exp $b$ $<1$. The final model was significant $\left[^{2}=5,371 ; p=0,02, R^{2}{ }_{\text {Nagelkerke }}\right.$ $=0,298]$. The Nagerlkerke R2 of the model summary was 0.298 , meaning that these independent variables can explain $29.8 \%$ of the dependent variable's observed variation.

When considering that 303 professionals used some input to prevent these lesions, professionals informed the usage of microporous adhesive tape as the primary input, 235 (75.3\%). When considering other inputs (some professionals indicated more than one product), 87 (27\%) participants (Table 5) reported the preventive effect.

A significant association was observed for the use of hydrocolloid plate and microporous adhesive/adhesive to prevent injuries. However, the odds of the association of hydrocolloid was $4.23(95 \% \mathrm{Cl} 1.335-13.454)$, indicating that those who used this input had a greater chance of preventing injury than those who did not use it, while the use of microporous adhesive/plate had odds of 0.251 ( $95 \% \mathrm{Cl} 0.079-0.797$ ), showing that the use of this input also did not reduce the chance of preventing injury.

\section{DISCUSSION}

The profile of professionals in this study resembles that of a multicenter study conducted in China at the time of the COVID-19 pandemic, in which out of a total of 4,308 physicians and nurses interviewed, the majority (88\%) were female, mean age 32.5 years ( \pm 7.1 years), the vast majority (67.4\%), under 35 years. Regarding the use of PPE, the same study indicated that the average time was 7.7 hours ( \pm 2.9 hours), with $85.7 \%$ using daily for a period longer than four hours ${ }^{(10)}$.

Regarding PPE's use, although the biosafety rules demand its use during the health care process, some professionals still do not use it in the indicated manner. A study conducted in Goiás, Brazil, demonstrated that $30 \%$ of nurses reported using such equipment is not common and only uses it sometimes ${ }^{(12)}$. Most professionals know the standard precautions measures, but the adherence attitude remains partial, and still present a risk behavior by not using masks and goggles ${ }^{(13)}$.

Thus, with the explosion of the number of cases of COVID-19, a severe problem is established for health professionals, who, besides the situation of not offering PPE, in some cases may still not be using it properly, including safe placement and withdrawal. In this study, even being carried out during a pandemic period, there were still registered professionals who referred not to use it according to the correct biosecurity practices and fundamental protocols for preventing this virus, which has high transmissibility power. And, for denying the risk of infection, even having access to PPE, those who did not use it justified it with the argument of unavailability.

The World Health Organization (WHO) has determined health professionals to assist in direct contact with the COVID-19 patient, in the hospital environment, to use the surgical mask, cloak, gloves, and eye protection (glasses or face mask). To perform aerosol-generating procedures in patients with COVID-19, use N95 or FFP2 mask, cloak, gloves, and eye protection ${ }^{(6)}$.

Due to the high transmissibility power of COVID-19(14), the listed PPEs need to be used for extended periods by health professionals to avoid infection, including withdrawal, which can result in skin lesions. Research conducted with 542 health workers identified some skin alteration due to the prolonged use of PPEs in $97 \%$ of participants. Among such alterations resulting from lesions pressure were: erythema, papules, maceration, and scaling ${ }^{(15)}$.

There is still no strong evidence on the development of these lesions. Some factors have been associated, such as intense sweating, male gender, time of daily use over four hours and over 35 years may increase the risk of skin lesions ${ }^{(10)}$.

In Brazil, no studies identified that characterized PL by using PPE among health professionals who attend patients with COVID-19. In this research, some associated factors were identified: professionals over 35 years of age, workload, and PPE use for more than six hours without using inputs for protection.

It is known that the same mechanical forces (i.e., pressure and shear) that cause pressure injuries in patients are also causing pressure injuries in healthcare professionals when they wear PPE, such as face masks (especially N95 masks) and goggles for long periods. Like in patients, three main factors influence the appearance of these injuries: pressure intensity (and shear), pressure duration (and shear), and tissue tolerance of the individual (including the effects of friction and moisture on tissue tolerance) $)^{(16)}$.

Regarding Medical Device-related Pressure Injury prevention, organizations worldwide have published guidance on strategies that can help prevent these injuries. However, there is no potential evidence to recommend these, so they should be used and monitored by dermatology services, stomatherapy and/or hospital infection.

Among the cares is skin hygiene with right products (soaps with acid $\mathrm{pH}$ ), application of sealant or skin protector (barrier cream), no use of oily products, use of good prophylactic dressings (when clinically necessary) to avoid pressure lesions or protect injured areas, removal of the mask from the face for 15 minutes, 
Pressure injury related to the use of personal protective equipment in COVID-19 pandemic Coelho MMF, Cavalcante VMV, Moraes JT, Menezes LCG, Figueirêdo SV, Branco MFCC, et al.

every two hours, outside the contact areas of the patient. If this period is not practical, the mask should be lifted from the sides for 5 minutes, every two hours ${ }^{(17,18)}$

The adjustment and sealing of PFF2/N95 masks in contact with the skin are necessary to provide an expected and significant airway exposure reduction. Thus, any product that reduces the fit and seal of PFF2/N95 can decrease the level of protection.

There is no clinically recommended usage for adhesive tapes and acrylate derivatives (microporous adhesive). Those tapes can interfere in the mask position and cause lesions related to adhesives during the removal since these are of strong adhesion to the skin, and it is fragile and humid ${ }^{(19)}$.

\section{Study Limitations}

Given the data presented and considering the population's distance condition, one of the limitations of this study was the impossibility of comparing more accurately the self-reported observations. Thus, it is essential to carry out observational studies to judge these lesions and other skin characteristics in a more straightforward way, such as hydration, $\mathrm{pH}$, and transepidermal loss.

\section{Contributions to the Nursing Area}

This is the first Brazilian study about health professional injuries occurrences caused by PPE's continued use during the confrontation of COVID-19. Understanding the behavior of these injuries will make it possible to establish preventive strategies. In this sense, this work provides subsidies for creating protocols and public health policies to provide safe, professional practice. Thus, it is possible to prepare professionals for similar situations that may occur in the future.

\section{CONCLUSION}

The study evidenced that the professionals participating in the study in the majority always wore personal protective equipment in practice during the COVID-19 pandemic and had a prevalence considered high for Medical Device-related Pressure Injury. In this population, the incidence of injuries was associated to the factors: no use of skin protection inputs, age over 35 years, working time and daily use of PPE longer than six hours/day, in the hospital environment.

\section{REFERENCES}

1. Yi Y, Lagniton PNP, Ye S, Li E, Xu RH. COVID-19: what has been learned and to be learned about the novel coronavirus disease. Int J Biol Sci 2020;16(10):1753-66. doi: 10.7150/ijbs.45134

2. Wei-jie G, Zheng-yi N, Yu H, Wen-hua L, Chun-quan O, Jian-xing H, et al. Clinical characteristics of Coronavirus Disease 2019 in China. N Engl J Med. 2020;382:1708-20. doi: 10.1056/NEJMoa2002032

3. Vilelas JMS. The new coronavirus and the risk to children's health. Rev Latino-Am Enfermagem. 2020;28:e3320. doi: 10.1590/1518-8345.0000.3320

4. Ministério da Saúde (BR). Secretaria de Atenção especializada à saúde. Departamento de Atenção Hospitalar, domiciliar e de urgência. Protocolo de manejo clínico da COVID-19 na atenção especializada [Internet]. Brasília: Ministério da Saúde; 2020 [cited 2020 May 20]. 48 p. Available from: http://189.28.128.100/dab/docs/portaldab/documentos/20200504_ProtocoloManejo_ver09.pdf

5. Secretaria Estadual de Saúde do Ceará. Boletim epidemiológico: doença pelo novo coronavírus (COVID-19). [Internet]. Fortaleza: Secretaria de Saúde do Estado do Ceará; 2020 [cited 2020 May 21]. 39 p. Available from: https://coronavirus.ceara.gov.br/wp-content/ uploads/2020/05/boletim_covid_n26_19_05_2020_v2.pdf

6. World Health Organization. Rational use of personal protective equipment for coronavirus disease (COVID-19):interim guidance, 27 February 2020. World Health Organization. [Internet]. 2020 [cited 2020 May 21]. Available from: https://apps.who.int/iris/handle/10665/331215

7. Chou R, Dana T, Buckley DI, Selph S, Fu R, Totten AM. Epidemiology of and Risk Factors for Coronavirus Infection in Health Care Workers. Ann Intern Med. 2020;M20-1632. doi:10.7326/M20-1632

8. Suleiman A, Bsisu I, Guzu H, Santarisi A, Alsatari M, Abbad A et al. Preparedness of Frontline Doctors in Jordan Healthcare Facilities to COVID-19 Outbreak. Int J Environ Res Public Health. 2020:17(9):3181. doi: 10.3390/ijerph17093181

9. Simon G, Baldwin DS. Covid-19: doctors must take control of their wellbeing. BMJ. 2020;369:m1725. doi: 10.1136/bmj.m1725

10. Jiang $Q$, Song S, Zhou J, et al. The prevalence, characteristics, and prevention status of skin injury caused by personal protective equipment among medical staff in fighting COVID-19: a multicenter, cross-sectional study. Adv Wound Care (New Rochelle). 2020;9(7):1-8. doi: 10.1089/ wound.2020.1212

11. Moraes JT, Borges EL, Lisboa CR, Cordeiro DCO, Rosa EG, Rocha NA. Concept and rating of pressure injury: update of the national pressure ulcer advisory panel. Revista de Enfermagem do Centro-Oeste Mineiro. 2016; 6(2):2292-2306. doi: doi: 10.19175/recom.v6i2.1423

12. Garcez GO, Tavares ER, Bernardes LLP, Dutra PVR, Valle OS, Álvares ACM. Use of PPE by primary care health professionals in a municipality of Goiás. REVISA. 2019;8(4):418-26. doi: 10.36239/revisa.v8.n4.p418a426

13. Passos EAD, Marziale MHP. Knowledge and attitudes of nursing professionals at a hospital in the brazilian state of São Paulo Regarding standard precautions. Cogitare Enferm. 2020;25(e66744):1-12. doi: 10.5380/ce.v25i0.66744

14. Diaz-Quijano FA, Rodriguez-Morales AJ, Waldman EA. Translating transmissibility measures into recommendations for coronavirus prevention. Rev Saúde Pública. 2020;54(43):1-4. doi: 10.11606/s1518-8787.2020054002471 
15. Wang JV, Parish LC. Dermatologic Manifestations of the 1918-1919 Influenza Pandemic. Skinmed. [Internet]. 2019 [cited 2020 May 21];17(5):296-7. Available from: https://pubmed.ncbi.nlm.nih.gov/31782701/

16. European Pressure Ulcer Advisory Panel, National Pressure Injury Advisory Panel, Pan Pacific Pressure Injury Advisory Panel. Prevention and Treatment of Pressure Ulcers/Injuries: Clinical Practice Guideline. Third ed: EPUAP-NPIAP-PPPIA; 2019.

17. Ramalho AO, Freitas PSS, Nogueira PC. Lesão por pressão relacionada a dispositivo médico nos profissionais de saúde em época de pandemia. ESTIMA, Braz J Enterostomal Ther. 2020;18(e0120):1-3. doi: 10.30886/estima.v18.867_PT 11

18. National Pressure Injury Advisory Panel (NPIAP). NPIAP position statements on preventing injury with N95 masks. [Internet]. 2020 [cited 2020 May 05]. Available from: https://cdn.ymaws.com/npiap.com/resource/resmgr/position_statements/ Mask_Position_Paper_FINAL_fo.pdf

19. McNichol L, Lund C, Rosen T, Gray M. Medical adhesives and patient safety: state of the science: consensus statements for the assessment, prevention, and treatment of adhesive-related skin injuries. Orthop Nurs. 2013;32(5):267-281. doi:10.1097/NOR.0b013e3182a39caf 